\title{
Blog-Based Learning Innovation with Powtoon Application in Facing Industrial Revolution 4.0
}

\author{
T M Siregar ${ }^{1}$, S Frisnoiry ${ }^{2}$ \\ 1,2Department of Mathematics Education, Medan State University, North Sumatera, Indonesia \\ Email: tiurmalasarinew2019@gmail.com
}

\begin{abstract}
The purpose of this research is to look at the feasibility of powtoon learning media on subjects by using blocks as learning resources, view responses to media using blocks on subjects, and see students' understanding ability after being given learning through powtoon media using blogs. The target of this research is lecturers and students who carry out learning with powtoon assistance at Medan State University. The method used to obtain the required information is to use the Google form questionnaire that is given online to lecturers and students and wants to see the understanding of students in using powtoon media. The results obtained from this study are Powtoon-assisted blog media in the Mathematics Learning Evaluation course declared valid with $88.2 \%$ included in the "very feasible" category, student responses to the media received a percentage of $90 \%$ included in the "very interesting" category, and occurred an increase in students' understanding of the Mathematics Learning Evaluation teaching material can be seen from the gain index of an increase of 0.61 which is categorized as a high or significant increase.

Keywords: learning innovation; Powtoon application; blog
\end{abstract}

\section{Introduction}

Situations that are developing and changing rapidly as at present, the sources of learning resources are actual, rich, and easy to reach. The internet is a technology that provides a strong foundation for the creation of a rich and flexible learning environment that is able to meet educational needs.

For this reason, it is necessary to make learning innovations. The innovation here is changing the way of teaching, from the traditional way to the present way, namely web-based learning. Many learning media are web-based, one of which is a blog.

In the use of blogs, lecturers can add various content; one of them is material. In addition to the use of interesting blogs, the material provided in blogs must also be interesting. One internet-based application that can display theory interestingly is the Powtoon application. Powtoon is a company that provides software for designing presentations. Unlike other software that must be installed on a computer before use, the powtoon does not need to be installed. Powtoon users immediately work on the Powtoon website as long as it remains connected via the internet. Powtoon provides a variety of basic templates and themes for presentation. Powtoon provides various types and colors of text, even simple animations for moving text. Typically, Powtoon provides various forms of cartoons from human-shaped cartoons to other objects commonly found in daily life. So, Powtoon is very suitable to be used as an alternative media in delivering subject matter.

The use of blogs in powtoon applications can enhance the industrial revolution 4.0, which is being acted upon, especially in the field of education. According to the German Chancellor, Angela Merkel (2014) argues that Industry 4.0 is a comprehensive transformation of all aspects of production in the industry through the merger of digital and internet technology with conventional industries. Schlechtendahl et al. (2015) emphasize the definition of the speed 
element of information availability, which is an industrial environment in which all entities are always connected and able to share information with each other.

\section{Research Method}

This research was conducted at Medan State University Faculty of Mathematics and Natural Sciences Department of Mathematics Education in odd semester 2019-2020. The subjects in this study were 33-semester students majoring in Mathematics Education.

This type of research used in this study is the 4D Development Research model adopted by Thiagarajan et al. (1974). The procedures for developing a performance assessment include (1) define, (2) design (planning), (3) develop, and (4) disseminate. The research instruments used in this study were questionnaires, comprehension ability tests, and documentation.

\section{Discussion}

\subsection{Define}

Based on the needs analysis, it is obtained that the learning blog in the Mathematics Learning Evaluation course has never existed in the Mathematics Department. Learning tends to be monotonous in the classroom. This was supported by the results of interviews with students who stated that students felt bored and difficult and were not interested in understanding the material in the Mathematics Learning Evaluation course. In addition, lecturers also rarely use the facilities provided by Medan State University. Because it is necessary to develop learning by utilizing the available facilities, namely by blogging.

\subsection{Design}

At this stage, researchers planned the development of web-based learning media, namely blogs. In the developed blog displayed learning needs in the form of lecture syllabus, material in the form of teaching materials and Powtoon media, LK, and assignments.

\subsection{Develop}

After the product has been successfully developed, the next step is to test the feasibility of the media by product validation. Product validation is done after making the initial product. Validation is done by asking experts/experts who are experienced in assessing the product being designed. The results of the validation carried out by three validators stated that the products that were done were included in the category of "very feasible" to be used for learning activities in the Mathematics Learning Evaluation course.

a. Media Effectiveness (Product Testing)

- Small Class Trial

Table 1. Small-Group Test Results

\begin{tabular}{|l|l|l|l|l|}
\hline Aspect & Total Score & Average & Percentage & Category \\
\hline Media display & 45 & 4,5 & $90 \%$ & Very interesting \\
\hline Grammar & 42 & 4,2 & $84 \%$ & Very interesting \\
\hline Ease of use & 40 & 4 & $80 \%$ & Very interesting \\
\hline Usefulness & 42 & 4,2 & $84 \%$ & Very interesting \\
\hline Total & $\mathbf{1 6 9}$ & $\mathbf{4 , 2}$ & $\mathbf{8 4 , 5 \%}$ & Very interesting \\
\hline
\end{tabular}




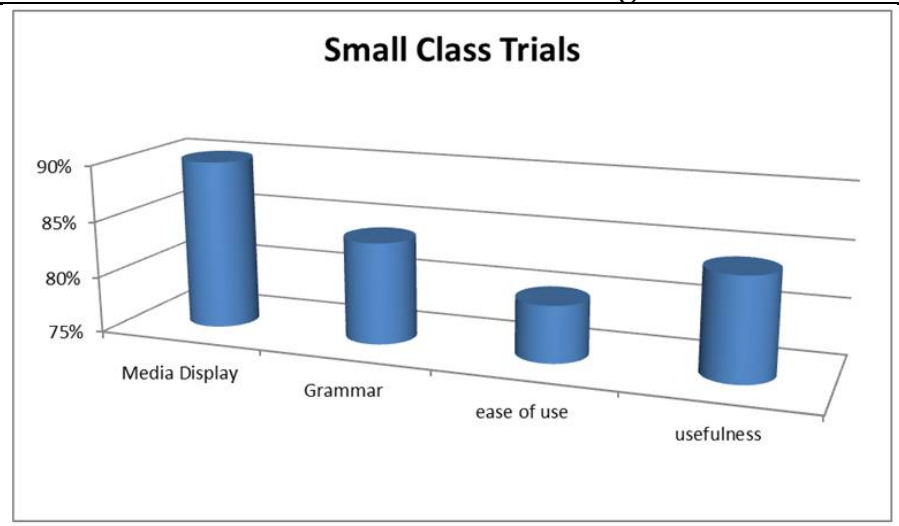

Figure 1. Percentage Graph of Small Class Trials

Based on a small group test conducted in the Department of Mathematics Education of 10 students who took the Mathematics Learning Evaluation course, data obtained on student responses were an average value of 4.2 with a percentage value of $84.5 \%$ included in the "very interesting" category. This means that the learning media of this blog is very interesting for students to be used as a learning medium.

- Large Class Trial

Table 2. Large Group Test Results

\begin{tabular}{|l|l|l|l|l|}
\hline Aspect & Total score & Average & Persentage & Category \\
\hline Media display & 140 & 4,2 & $85 \%$ & Very interesting \\
\hline Grammar & 155 & 4,6 & $94 \%$ & Very interesting \\
\hline Ease of use & 147 & 4,5 & $89 \%$ & Very interesting \\
\hline Usefulness & 152 & 4,6 & $92 \%$ & Very interesting \\
\hline Total & $\mathbf{5 9 4}$ & $\mathbf{4 , 5}$ & $\mathbf{9 0} \%$ & Very interesting \\
\hline
\end{tabular}

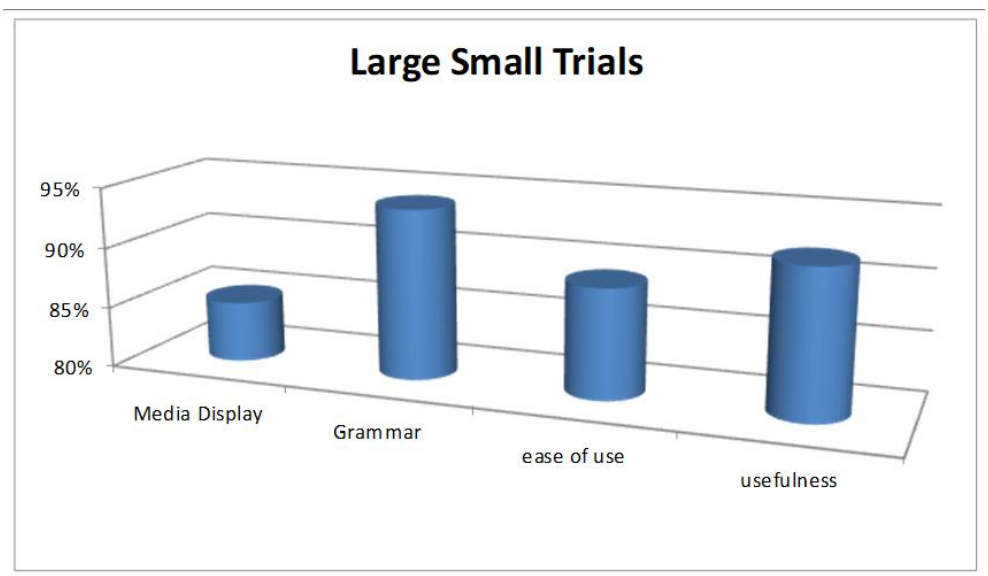

Figure 2. Percentage Graph of Large Class Trials

The total value of the overall average questionnaire response was 4.5 , with a percentage of $90 \%$ included in the "Very Interesting" category. This means that blog learning media developed for students is very interesting if used in learning activities, especially in the Mathematics Learning Evaluation course.

After going through the initial product development process, validation by experts/experts, the feasibility test to small groups, and finally the large group test, it can be 
concluded that the blog learning media in the Mathematics Learning Evaluation course is declared very feasible to be used as a learning medium.

After students carry out learning activities using Powtoon-assisted blogs, students are given questions with the aim of seeing students' understanding of Mathematics Learning Evaluation teaching materials. The results can be seen from the table below.

Table 3. Data on Improving Students' Understanding Ability

\begin{tabular}{cccccc}
\hline \multirow{2}{*}{$\begin{array}{c}\text { Average } \\
\text { Assessm }\end{array}$} & & Pre & Post & Gain \\
\cline { 2 - 6 } -test & & -test & & \\
ent aspects & 8 & 50. & & 81.2 & 0.61 \\
\hline
\end{tabular}

Based on the table above shows an increase in the average value of students' mathematical understanding ability from pre-test to post-test. Based on the gain index, an increase that occurs is 0.61 , which is categorized as a high or significant increase. This means that Powtoon-assisted blog learning media can help improve students' understanding of abilities in learning Mathematics Learning Evaluation teaching material.

Blog media product development has gone through several stages, ranging from needs analysis, initial product design, validation to experts, improvement based on expert advice, due diligence in small groups of 10 students of the Department of Mathematics Education who took Mathematics Learning Evaluation courses, revised accordingly suggestion, then the feasibility test for a large group is done during the Mathematics Learning Evaluation learning activities using blog media. The final results show a very high level of eligibility, which is $88.2 \%$, and student responses to media blogs are also very high, at $90 \%$.

In addition to the media being valid and feasible to use and getting positive responses from students, this media learning powtoon-assisted blog can also help improve students' understanding of teaching materials, especially Mathematics Education Evaluation material. Students feel more enthusiastic in learning so that it has a direct impact on student understanding. As revealed by Rusmana (2012), revealed in his research that ICT learning media has an influence on students 'understanding and is effectively used as a means of increasing students' understanding ability. Next, Anggraini (2016), concluded in his research that there is a significant difference in understanding before it after applying learning media in learning activities.

Therefore, based on the explanation and research that has been done, it can be concluded that the learning media of the Powtoon-assisted blog in the Mathematics Learning Evaluation course developed is valid and feasible to use and can help in increasing student understanding in the learning process.

\section{Conclusion}

The conclusion of this research is the development of Powtoon-assisted blog media in Mathematics Learning Evaluation subject declared valid, with $88.2 \%$ included in the category of "very feasible," meaning that Powtoon learning media is very worthy of being used as a learning medium in the Anatomy course. Student responses to the media get a percentage of $90 \%$ included in the "very interesting" category, which means that Powtoon media products are very interesting to be used as a learning medium for students. An increase in students' understanding of the Mathematics Learning Evaluation teaching material can be seen from the gain index of an 
increase of 0.61, which is categorized as a high or significant increase. The conclusion of this research is the development of Powtoon-assisted blog media in the Mathematics Learning Evaluation course, which is declared valid and suitable for use as a learning medium in Mathematics Learning Evaluation learning activities.

The suggestion that researchers give to instructors (instructors) that media learning by Powtoon-assisted blogs can be used in the learning process, and for instructors or researchers can further develop blogs and Powtoon in Mathematics Learning Evaluation courses or other subjects that have not yet been developed with more interesting animations.

\section{References}

Anggraini, S., Khairurradzikin. (2016). Efektivitas Pembelajaran Menggunakan Media Pembelajaran Macromedia Flash Dalam Meningkatkan Pemahaman Konsep Fisika Materi Hukum Newton. Jurnal Biotek. Volume 4. Nomor 2. Desember 2016.

Merkel, A. (2014). Speech by Federal Chancellor Angela Merkel to the OECD Conference. https://www.bundesregierung.de/Content/EN/Reden/2014/2014-02-19-oeced-merkelparis_en.html, Accessed on 03 May 2019

Rusmana, IM. (2012). Efektifitas Penggunaan Media ICT dalam Peningkatan Pemahaman Konsep Matematika. Jurnal Formatif. Volume 2 Nomor 3

Schlechtendahl, J., et al. (2015). Making existing production system Industry 4.0-ready. Production Engineering, Vol. 9, Issue. 1, pp. 143-148

Thiagarajan, Sivasailam, et al. (1974). Instructional Development for Training Teacher of Exceptional Children. Washington DC: National Centre for Improvement Educational System. 